DOI https://doi.org/10.30929/2307-9770.2020.08.01.05

UDC 37-042.4:004:[811.111+379.8:052]:(045)

\title{
Empiric research related to information technologies application in professional English learning process for tourism specialty students
}

Vasylyshyna N. *

National aviation university, Kyiv, Ukraine

Received: $02.03 .2020 \quad$ Accepted: 23.03 .2020

\begin{abstract}
In this paper the role of globalization on society has been discussed and in particular, the consequences of globalization's direct impact on the process of learning English by tourism graduates in higher education. Also, during the conducted survey, it was emphasized that over the past few decades advancements in information technology have had a profound on the global landscape as well as on the progression of globalization. The goal of this research is to investigate the positive effects of the application of information technologies in the professional English learning process for tourism specialty students. The research is focused on defining the benefits of incorporating them into the way of acquiring necessary language skills and abilities by tourism specialty students. The data used is collected from official documents, articles, reports, and the sources of organizations in the field of education. The findings of this research draw attention to the speedy infusion of information technologies into the field of education. Some of these outcomes are as follows: firstly, it has been discovered at this point that the active usage of information technology has become an integral part of the tourism students' preparation in the frame of tertiary education; secondly, it has been revealed and justified on the developed structural-functional model that the technology provides the means by which the English learning efficiency can be increased assisting tourism specialty students in competing and maintaining a completive professional advantage in the global environment and marketplace as well. Furthermore, the present article is an attempt to understand, analyze and provide an overall picture on basic aspects of English for Specific Purposes (English for Tourism): its definition, scope, characteristics and aims. Despite the English for Tourism teaching objectives, it also discusses the structural-functional model of modern information technologies usage in the educational process on the example of studying the module "Global tourism: International Benefits and Threats". Broadly speaking, the designed investigation related to information technologies application in professional English learning process for tourism specialty students has vividly witnessed its unbiased value and beneficial implementation in the higher education system. Our statement can be supported with a plenty of persuasive facts, such as follows: modern tools make English for Tourism learning process much more interesting, flexible, available; newest technologies are supposed to shape "soft skills" in tourism specialty students making them more competitive on the tourism global marketplace. To summarize, information technology benefits both traditional education institutions and online educational models of learning English for Tourism in fundamental ways.
\end{abstract}

Key words: globalization impact; tertiary education; information technology benefits; English for Tourism; teaching goals; foregn language skills, abilities; structural-functional model; tourism specialty graduates.

\section{Емпіричне дослідження стосовно застосування інформаційних технологій у процесі вивчення професійної англійської мови студентами спеціальності «туризм»}

\section{Василишина Н. М.}

Національний авіаційний університет, Київ, Україна

\begin{abstract}
Анотація. У цій роботі розглянуто роль глобалізації для суспільства, зокрема, наслідки її прямого впливу на процес оволодіння англійською мовою студентами спеціальності «Туризм" у вищій школі. Також, під час проведеного дослідження було підкреслено, що за останні кілька десятиліть просування в галузі інформаційних технологій позначилося як на глобальному рівні, так і на прогресуванні глобалізації. Мета цього дослідження - показати позитивні наслідки застосування інформаційних технологій у процесі навчання професійної англійської мови для студентів спеціальності «Туризм». Наукова робота зосереджена на
\end{abstract}

Corresponding Author: Vasylyshyna Nataliia. Tel. +38(068)593-07-27. E-mail: filologyN@gmail.com. National aviation university, Otradnyy Av., 4, Kyiv, Ukraine, 03143.

Відповідальний автор: Василишина Наталія Максимівна. +38(068)593-07-27. filologyN@gmail.com. Національний авіаційний університет, проспект Відрадний. 4, м. Київ, Україна, 03143. 
визначенні основних переваг залучення інформаційних технологій до процесу формування мовленнєвих навичок у студентів спеціальності «Туризм». Результати дослідження були отримані на базі розгляду офіційних документів, статей, звітів та джерел організацій у галузі освіти. Наукові розвідки свідчать про швидку популяризацію інформаційних технологій у сфері освіти. Деякі з цих результатів такі: по-перше, нами було виявлено, що активне використання інформаційних технологій стало невід'ємною частиною підготовки студентів спеціальності «Туризм» в рамках вищої освіти ; по-друге, розроблена структурно-функціональна модель доводить, що саме ця технологія сприяє підвищенню ефективності навчання професійної англійської мови , в той самий час допомагаючи студентам спеціальності «Туризм» конкурувати та мати значну перевагу фахової підготовки в глобальному середовищі та на ринку праці. Крім того, представлена стаптя - це спроба зрозуміти, проаналізувати та надати загальне уявлення щодо основних аспектів англійської мови за професійним спрямування (в даному дослідження сфери туризму), а саме: визначення поняття, характеристики та цілей. Крім виділення цілей навчання англійської мови за професійним спрямування, емпіричне дослідження також демонструє структурно-функціональну модель використання сучасних інформаційних технологій в навчальному процесі на прикладі вивчення модуля «Глобальний туризм: міжнародні переваги і загрози». Загалом, розроблене дослідження, пов'язане із застосуванням інформаційних технологій у навчанні англійської мови за професійним спрямуванням для студентів спеціальності «Туризм», яскраво засвідчило його неупереджене значення та застосування у системі вищої освіти. Наше твердження може бути підтверджено великою кількістю переконливих фактів, таких як: сучасні інформаційні технології роблять процес навчання набагато цікавішим, гнучкішим, доступнішим; новітні технології повинні формувати комунікативні вміння у студентів, роблячи їх більш конкурентоспроможними на світовому ринку туризму. Підводячи підсумок, слід зазначити, що інформаційні технології відіграють велике значення як для традиційних навчальних закладів, так і для освітніх моделей он-лайн у процесі вивчення англійської мови для сфери туризму сучасними студентами..

Ключові слова: вплив глобалізації; вища освіта; переваги інформаційних технологій; англійська мова для туризму; навчальні цілі; майстерність; вміння та навички; структурно-функціональна модель; студенти спеціальності «Туризм».

\title{
Эмпирическое исследование относительно применения информационных технологий в процессе обучения студентов специальности «туризм» профессиональному английскому языку
}

\author{
Василишина Н. М.
}

Национальный авиационный университет, Киев, Украина

\begin{abstract}
Аннотация. В этой работе рассмотрена роль глобализации для общества, в частности, последствия ее прямого влияния на процесс овладения английским языком студентами специальности «Туризм» в высшей школе. Также, в ходе проведенного исследования было подчеркнуто, что за последние несколько десятилетий продвижения в области информационных технологий сказалось как на глобальном уровне, так и на прогрессировании глобализации. Цель этого исследования - раскрыть положительные последствия применения информационных технологий в процессе обучения профессионального английского языка для студентов специальности «Туризм». Научная работа сосредоточена на определении основных преимуществ привлечения информационных технологий в процесс формирования речевых навыков у студентов специальности «Туризм». Результаты исследования были получены на базе рассмотрения официальных документов, статей, отчетов и источников организаций в области образования. Научные исследования свидетельствуют о скорой популяризации информационных технологий в сфере образования. Некоторые из этих результатов следующие: во-первых, нами было выявлено, что активное использование информационных технологий стало неотъемлемой частью подготовки студентов специальности «Туризм» в рамках высшего образования; во-вторых, разработана структурно-функциональная модель доказывает, что именно эта технология способствует повышению эффективности обучения профессионального английского языка, в то же время помогая студентам специальности «Туризм» конкурировать и иметь значительное преимущество профессиональной подготовки в глобальной среде и на рынке труда. Кроме того, представленная статья - это попытка понять, проанализировать и дать общее представление об основных аспектах английского языка профессиональной направленности (в данном исследования сферы туризма), а именно: определение понятия, характеристик и целей. Кроме выделения целей обучения английскому языку по профессиональному направлению, эмпирическое исследование также демонстрирует структурнофункциональную модель использования современных информационных технологий в учебном процессе на примере изучения модуля «Глобальный туризм: международные преимущества и угрозы». В общем, разработанное исследование, связанное с применением информационных технологий в обучении профессиональному английскому языку для студентов специальности «Туризм», ярко показало его значение и применение в системе высшего образования. Наше утверждение может быть подтверждено большим
\end{abstract}


количеством убедительных фактов, таких как: современные информационные технологии делают процесс обучения намного интереснее, гибче, доступнее; новейшие технологии должны фрормировать коммуникативные умения у студентов, делая их более конкурентоспособными на мировом рынке туризма. Подводя итог, следует отметить, что информационные технологии играют большое значение как для традиционных учебных заведений, так и для образовательных моделей онлайн в процессе изучения английского языка для сфреры туризма современными студентами.

Ключевые слова: влияние глобализации; высшее образование; преимущества информационных технологий; английский язык для туризма; учебные цели; мастерство, умение и навыки; структурнофункциональная модель; студенты специальности «Туризм».

\section{Introduction}

Problem Statement. Globalization really came to being in the latter part of the 20th century with advances in information technology. Information technology was the driver in creating the worldwide integration of various global markets that make up globalization. It would again be near impossible to discuss every influential technological advance over the past 30 years, but there are a select number of advances that truly have had a monumental impact on the progression of globalization and its relationship with business.

1. Rise of the Personal Computer. The rise of the Windows-based PC, which popularized personal computing, eliminated another important barrier that was restricting globalization: the limit on the amount of information that an individual could obtain, author, modify, and distribute. The PC allowed individuals to author their own digital content and share them with places all around the world.

2. Digital, Mobile, Personal and Virtual Movement. More recently the world has been swarmed with digital cameras, mobile PDA's and cell phones along with personal laptops and this is having a profound effect on the progression of globalization. With the growing popularity of these types of technologies individuals and companies are able to collaborate with one another more frequently and in so many more ways than ever before [1].

There are technologies such as instant messaging that allow people to communicate instantaneously, and they can be located anywhere around the world as long as they have a running internet connection and a messaging service. In this way companies can communicate with clients and employees who are around the world and give them the latest news that they may need to know in order to do business with clients or other companies [3].

Moreover, globalization and technological advancement have strikingly changed our ways of learning and teaching English as a lingua franca in the 21st century. The fast-growing information technology and the global network society have stimulated us to re-conceptualize international language use and foreign language learning and teaching as a multi-way process involving "flows of ideas, ideologies, people, goods, images, messages, technologies and techniques", has maximized the spread of English since nations have needed to utilize English as a lingua franca to develop their international trade, business and economics view, while globalization has eased the spread of the English language, the English language also functioned as a tool for international communication to contribute to the globalization process [2].

As Crystal states, globalization has also initiated the age of information technology requiring the deployment of the Internet whose main language is English. Markee indicates that the spread of information technology worldwide is strongly linked with the diffusion of the English language.

To put it differently, it can be stated that while English has contributed to the proliferation of this technology, the information technology has also boosted the diffusion of English through Internet communication. Furthermore, because a number of studies in scientific-technological areas have been conducted in English, people are to have a basic knowledge of English to conduct research. According to Zhu, that people need knowledge of English to obtain information has promoted the status of English to lingua franca which in turn has influenced the language teaching in the world. This paper, hence, aims at investigating how globalization and information technology has affected English language teaching policy [3].

This paper discusses the role of information technology in teaching English language. The problem of learning languages is very important today. Ukraine is integrating into the world community and the problem of learning English for the purpose of communication is especially urgent today. To know English is absolutely necessary for every educated person, for every good specialist. Learning an English language is not an easy thing. Towards the end of the late 1800 s, a revolution in language teaching philosophy took place that is seen 
by many as the dawn of modern foreign language teaching. Different methods appeared, such as: Grammar Translation Method, the Direct Method, Audio-Lingual Method and others. Information technology may assist in the facilitation of learning or serve as the actual educational structure allowing learning to occur [4].

Information technology helps the students as well as the teachers in studying the course material easily because of fast access. Studying the subjects with the help of online libraries and dictionaries has made grasping and increasing the knowledge easy for the students. The inclusion of information technology in the syllabus in schools, colleges and universities has helped them in grasping the subject well and getting their basics cleared [5].

Since, many educational centers have the online grading system, it has been a boon for the parents of the children to keep a tab on their performances. Parents can also get the details of the attendance record of their child [6], [7].

With laptops, tablet computers and other mobile devices playing an increasingly important role in education today, developing an understanding of information technology- both as its own topic and as a part of other subjects- is becoming more vital. The information society challenges the education system.

In recent years, the speedy, effective and global communication of knowledge has created a new foundation for co-operation and teamwork, both nationally and internationally. The increasing role played by information technology in the development of society calls for an active reaction to the challenges of the information society. Advancements in information and communication technology can play an important role in preparing students to apply what they learn in any subject to finding their place in a global workforce [5], [7].

Information technology may assist in the facilitation of learning English or serve as the actual educational structure allowing learning to occur. For example, multimedia presentations, knowledgemanagement software, video-conferencing, cloud computing and collaborative document editing are notable information technology services benefiting education. Advancements in information and communication technology have not only benefited education, but also continue to shape the way the field itself develops. With more powerful software and applications, along with mobile devices such as tablet computers, personal digital assistants and laptops becoming more prevalent in the classroom, information technology offers many benefits to all aspects of education [7].

Equally important to highlight that the process of development the higher education is closely connected with the improvement of the quality of training specialists process, with dynamically developing research and innovative education. The social environment and economic needs of university research is aimed at improving the education system and information technology. In the conditions of the modern world, the primary task of the education system is the training of highly qualified specialists that meet all the requirements of modern reality.

To improve the level of education, it is necessary to form methods of increasing organizational and educational quality, as well as actively introduce pedagogical innovations. The education system should be supplemented by new content and tasks, modern conscious education and a new quality education that meets the high demands of the modern world. Based on this approach, we can argue that in the process of preparing future specialists based on the credit system of education, innovation takes priority place. The relevance of this issue increases with the training of specialists whose activities are directly related to the creative process [8].

As a result of the introduction the information technologies changes to the English learning process, the number of lecture hours were reduced, the main emphasis was placed on independent work carried out using a computer. The modern system of training provides an opportunity for the learner to plan the educational process on his own. Educational work is assessed by the volume of the educational material.

The introduction of new educational technologies is connected with automation of educational and methodological complexes and plans and of course the selection of students by the trajectory, in the organizational automation of the educational process with the credit technology calculates the tutor's load- that is, in the use of information technology [8], [9].

Today, information technologies are widely used in production, enterprises, document circulation and record keeping; the areas covered by these technologies are expanding day by day. According with this increase the volume and complexity of the information being processed, a new visualization has become necessary in the society. The use of information technologies in the formation of professional competencies of 
future tourism specialists is one of the basic requirements for modern information development of society [8], [10].

Obviously, in the information society there is an objective need for tourism area specialists who are able to quickly adapt to the changing content of work activity, having the opportunity to quickly learn new knowledge and skills. Qualitative improvement of the foreign language educational process is related to the educational information and the effective use of these technologies in the organization of the learning process. An important element in the formation of the tourism student's foreign language professional competencies is mastering English for Tourism skills in order to be competitive and profound on the global tourism market [10].

Latest Researches and Publications Review. From the the second half of the 20th century, English for Specific Purposes has grown to become one of the most prominent areas of English foreign language teaching today. Long scientific debates in this domain and shared opinions amongst educators have resulted in defining ESP as the area of inquiry and practice in the development of language programs for people who need a language to meet a predictable range of communicative needs. Therefore, English for Specific Purposes today presumes teaching of English as a foreign language regarding specific profession, subject or purpose [11].

T. Hutchinson [12] noted that two key historical periods breathed life into ESP. The second was the Oil Crisis of the early 1970s resulted in Western money and knowledge flowing into the oil-rich countries; the language of this knowledge became English. The birth of ESP and its origin have been much discussed by the scientific elite and successfully led to stating three reasons common to the emergence of all ESP: the demands of a Brave New World, a revolution in linguistics, and focus on the learner:

- the first reason means the expansion of demand for English to suit specific needs of a profession. Whereas English had previously decided its own destiny; rather, it now became subject to the wishes, needs and demands of people other than language teachers;

- the second reason is the developments in the field of linguistics. The attention shifted from defining formal language features to discovering the ways in which language is used in real communication, causing the need for the development of English courses for specific group of learners [13].

The analysis of theoretical literature concerning ESP phenomenon has shown that it sprang into being in 1950s and 1960s when there was an expansion of scientific, technical and economic activities on an international scale referring to the works of

T. Dudley-Evans and S. John. It gradually developed into a multilayered complex language approach which primarily based on learners' specific needs required by their professions or occupations. The area of linguistic interest labeled as ESP was proven to have a universal dimension through the concept of language for specific purposes and a language-specific perspective through the insights explored into various European languages [13].

For the last decades, there have been conducted numerous studies on different aspects of ESP ( $T$. Dudley-Evans, T. Hutchinson, P. Strevens, H. Basturkmen; the series of works are dedicated to the importance of learners' needs analysis and target situation analysis in the process of ESP teaching ( $T$. Hutchinson, R. West, M. Long). Some works are devoted to ESP curriculum development (H. H. Stern, J. Ewer). The significant researches have been conducted on the aspects of discourse and genre analysis in ESP teaching and different approaches to the learning of ESP (T. Dudley-Evans, T. Hutchinson, D. Biber, C. Candlin, N. Fairclough, A. Henry, T. Yakhontova, O. Synekop) [14], [15], [16], [17], [18], [19], [20], [21], [22].

The problem of ESP is not new to Ukrainian higher educational system. Of great interest here are the researches dedicated to ESP courses, including the courses for business students and of information sciences (S. Dyudyakova), for students in travel and leisure management, for the students in engineering (I. Chirva), and for the students of medicine. For instance, Y. Bulakhova proposed integrated multimedia use while teaching students of information sciences, V. Strilets focused on teaching reading and writing, implementing a project to create a site with a focus on its content for those studying business [13], [23].

The evolution of technology has brought about with it, several benefits the world over. Apart from enhancing efficiency, it has turned the world into a global village and made access to information quite easy. The education sector has also not been left behind in tapping into the deep resource-well of technology. The use of information technology during English studying process has become more than just an option. For 
effective foreign language learning, the education sector stakeholders have found ways of integrating the use of information technology in the everyday learning processes.

On the way of our investigation we are going to analyze the main reasons why IT (Information Technology) is essential in education.

1. Access to learning the material. The internet is full of a lot of learning material that the learner can access and use to supplement whatever is provided for in the classroom. There are e-books, revision guides and past examination papers that are available on the world wide web and students can take advantage of these to improve their knowledge base. Learning institutions provide computers and internet that the students can use to this end [24].

2. Continuous learning. In the modern world, you don't have to be in the classroom to learn. Using information technology in education has made it possible for students to keep on learning, irrespective of where they are. Teachers and professors can send assignments to students and they can complete and submit them even without physically stepping into the classrooms and so learning never has to stop. Students can keep on learning even when they are at home. This has greatly enhanced efficiency in the education sector [24].

3. Sharing of knowledge. Through online discussion forums, students can share knowledge, engage in intellectual debates and generally learn from one another. Using information technology in education has basically made it possible for students from all over the world to come together and share experiences, the geographical distances notwithstanding. Information technology in education has also made students develop an appreciation for cultural diversity and in turn, create a more tolerant and unified world [24].

4. Using audio and visual material as learning aids. The use of information technology in education has made it possible for tutors to teach students much more easily. By using audio and visual materials, students can develop a better understanding of the topics being taught. It is now much easier to perform demonstrations and put some practical aspect to the theory taught in class. Slow learners, therefore, have an opportunity to catch up with those who had grasped whatever was initially taught in class [24].

5. Distance learning. To adapt to a changing population with unique demands, learning institutions have employed the use of information technology in education to cater to this new demographic. Online courses have enabled most of the employed and young population to go back to class and get second degrees or additional certifications. It is possible to attend a college overseas without even getting out of your home country and at your own convenience [24].

6. Proper record keeping. It is possible to keep student records in a more systematic and secure manner using technology. Unlike in the past when records used to be kept manually and there were many cases of lost files, the incorporation of information technology in education has made it possible for safe and proper record keeping. Retrieving of information has, therefore, become much easier [24].

Taking into consideration the deep analysis of numerous literature sources [13], [14], [15], [16], [17], [19], [22], [23], we have made a summary that information technology used in the classrooms enhances lessons and instructions. Having up to date information and research available with only a mouse click as well as the internet, ensures that the students have accurate and viable information. It is no wonder that students are encouraged to undertake a treasure hunt of knowledge and gather information on specified topics. Their creativity is triggered with various views and images amassed from across the globe. Be it projects, assignments, presentations or exchange of information from one destination to another, students know how to roast the roost and admirably present their viewpoint.

Many educators are looking at ways of applying the technology to every subject and change the way teachers and students approach them. By digitally organizing what was once on paper, we have easier access to important information as well as a valuable tool in decision making. Many libraries use a digital database to make information readily available and make the education process smoother. This has also paved way for the educators to interact with colleagues via video conferencing, access and gather data in the maintenance of records as well as use of more multi-media rich applications and programs to plan more effective and interactive lessons [19], [21],[22], 25].

Improved communication is facilitated within the school system, community and the families of the students. Schools that utilize internet based systems for student grades, attendance details, discipline records and homework information instantly convey the same to the parents. Special events, instructional calendars, 
links to educational sites are all available on the school websites. Schools can broadcast lessons to multiple classrooms simultaneously as a means of offering courses in low-enrolment subject areas. This also allows students in remote locations to have direct interaction with teachers at a central location. Distance education has become increasingly global, within the reach of people across the world [25].

Society is the recipient of the final product, the student, of the educational system. The student must be prepared to face the challenges of a society and job market focused on technology. IT is a versatile tool which when properly used, greatly assists learning in all areas. Furthermore, mastery of the use of those tools will equip students with invaluable skills to use in the various vocations they subsequently take up. Probably it's time to ride full steam on the bandwagon of information and communication technology [25].

For this reason, language teaching in general and English language teaching in particular has tremendously changed over the centuries. Language learning and teaching are dynamic, fluid, mutable processes, so there is nothing fixed about them unlike the teaching of other subjects. Language teaching especially throughout the twentieth century underwent numerous changes and innovations. Approximately, every decade a new approach or methodology comes into practice.

Many major theories, events, trends and technologies which shaped English language teaching during the past decades suggest methodologies are as much a product of their times as educational systems, and rooted in the ideas of their time. Ideas may come into and go out of fashion. Many new approaches are rediscoveries of old methods neglected but re-illuminated. English language teaching practitioners around the globe have been practicing different trends suitable to their context, needs, availability of resources and practicality. Teachers have had a large amount of methods offered at different times [26].

Obviously, some teachers stick on certain methodologies very sternly. Nonetheless, majority of the English language teachers instead of adhering to prescribed trends, follow different ones at different times applicable to their contexts. Besides, they practice different educational technologies to grow academically and professionally. Educational technologies, especially computers and computer-related peripherals, have grown tremendously and have permeated all areas of our lives. It is incomprehensible that anyone today would argue that banks, hospitals, or any industry should use less technology. The Internet in particular is becoming an increasingly vital tool in our information society. More people are going online to conduct such day-to-day activities as education, business transactions, personal correspondence, research and information-gathering. Each year, being digitally connected becomes ever more critical to educational advancement [26].

Purpose of the Thesis. The main goal of the article is to encompass fruitfully, sufficient, tremendously vital findings related to theoretical argumentation of the information technologies application in the frame of foreign language teaching for specific purposes aims together with empirical provision of the survey results presented in the form of structural-functional model of English for Tourism study by tourism specialty students.

\section{Materials and Methods}

This study was conducted in the largest tertiary education institution in Ukraine, on the Faculty of International Relations with students on specialty "Tourism" which among other programs provides wellacknowledged internationally accredited higher education in tourism. The purpose of the research is to study contemporary educational needs and to increase tourism students' knowledge, skills and abilities of their professional English language necessary for work in tourism business and determine opportunities for curriculum development on the basis of developed structural-functional model.

Furthermore, the presented research is based on the background of modern methodology, in particular is grounded on the bundle of several methods of scientific research. Under the method we mean the way of theoretical study and the practical implementation of information technologies in English for Tourism learning process.

Also, method is a tool for solving the main task of discovery of objective laws of education reality. The method is an abstract-theoretical expression of the laws between some facts and the process of cognition itself, that is, the way of knowing, based on a certain set of previously received total knowledge.

In addition, the method is a set of special techniques, rules, procedures that regulate the process of cognition and provide solutions to the research problem related to foreign language competence of tourism specialty students increase. 
Specifically, we applied such methods as: analysis (English for Tourism study is divided into parts and each of them is investigated separately; synthesis - parts of the dismembered object come together and the object is known as holistic formation and simulation is a method of cognition that is to replace the object under study its analogue (model), which checks the characteristics of the original, namely structural-functional model of learning English for Tourism.

\section{Results}

Over the last decades, discussion regarding the quality of education and its correspondence to the needs of industry has been on the agenda worldwide. Under the influence of globalization and the world-wide economic downturn, it is especially important to create or update curricula so that they would correspond to rapidly changing market needs and would help educate employees who will be working in situations that are currently difficult to predict.

The strategic document "Europe 2020" points to three priorities in order to overcome the problems and face the future: smart growth, sustainable growth and inclusive growth. This means the development of 'economy based on knowledge and innovation', promoting a green, efficient and competitive economy and "fostering a high-employment economy". In order to attain this goal it is necessary to create new curricula and adapt the existing ones so that they would ensure social cohesion and be innovative and develop creative personalities. To do this, higher education institutions try to establish close contacts with the industry to follow all changes and development [27].

The World Tourism Organization "TedQual" program, whose objective is to improve the quality of tourism education, training and research programs, has defined evaluation criteria for tourism curricula. Among other components the degree of incorporation of stakeholder needs, both the needs of the tourism industry and its students, into the programs are evaluated. In this respect, Tourism Education Futures Initiative has formulated a set of five values-based principles that tourism students should embody upon graduation in order to become responsible leaders and stewards in their field: ethics, stewardship, knowledge, professionalism, and mutuality. According to the principle of ethics, students should be able to identify sources of power, provide ethical leadership and initiate changes for the better. Knowledge includes creativity, critical thinking and networking through complex of reasoning, learning, communication, a association and application. Describing stewardship, Tourism Education Futures Initiative emphasizes that students should be encouraged to question everything, including what their professors say. Professionalism is defined as a complex of leadership skills, practicality, reflexivity, team working and partnership building skills, and proactivity. It means not only the skills, competences or standards, but also attitude and behavior. Mutuality is characterized as self-respect and respect for others, which could be developed through open interactions, constructive communication and discussions, conflict avoidance and management, empathy and acceptance [27].

To conform to the requirements of the five aforementioned principles, improvements are needed in the spheres of the learning and teaching environments, curricula revision and development. Tourism curricula have to be updated, reflecting a more realistic view of the industry [27].

$H$. Stern distinguished four types of ESP teaching objectives: proficiency, know- ledge, affective, and transfer. Proficiency objectives concern mastery of skills such as reading, writing, listening, and speaking. Knowledge objectives concern the acquisition of linguistic and cultural information, where linguistic knowledge objectives include language analysis and awareness of the systematic aspects of language, cultural knowledge objectives include control of socio-cultural rules i.e. mastery of the norms of society, values, and orientations and the ability to recognize culturally significant facts, knowing what is acceptable and what is not. Affective objectives concern the development of positive feelings toward the subject of study; they include attitudes toward attaining second language competence, socio-cultural competence, and language learning. Transfer objectives concern the ability to generalize from what has been learnt in one situation to other situations [21].

In its turn, $\mathrm{H}$. Basturkmen describes the five broad objectives in ESP teaching:

1) revealing subject-specific language use;

2) developing target performance competencies;

3) teaching underlying knowledge; 
4) developing strategic competence and

5) fostering critical awareness [16], [17].

Revealing subject-specific language use is linked to the linguistic knowledge objective and to the cultural knowledge objective in the categorization of $\mathrm{H}$. Stern.

Teaching oriented to this objective aims to show how English is used in the target environment and to impart to students the knowledge about it that has been revealed by linguistic research in the field. Developing target performance competencies can be described as an approach focused on developing the ability to perform the activities of an occupation and function to the standards expected of those employed in that occupation.

She also adds that teaching oriented toward this objective presents language operationally in terms of what people do with language and the skills they need to do it. Courses are organized around core skills and competencies that are also subdivided into micro-skills and more specific competencies. This orientation can be categorized as a proficiency objective, according to $\mathrm{H}$. Stern's classification [28].

Teaching underlying knowledge means that the ESP teacher should be aware of the fact that using a second or foreign language for workplace or study purposes requires not only linguistic proficiency and knowledge but also knowledge and understanding of work-related and disciplinary concepts. Developing strategic competence refers to a three-part model of specific-purpose language ability comprising language knowledge (grammatical, textual, functional, and sociolinguistic), background knowledge, and strategic competence (assessment of the external context and engaging a discourse domain) [28].

As D. Douglas argues, strategic competence acts as a "mediator" between the external situational context and the internal language and background knowledge that is needed to respond to the communicative situation. Strategic competence is the link between context of situation and language knowledge and can be defined as the means that enables language knowledge and content knowledge to be used in communication. Fostering critical awareness means in this context to help English language learners meet the demands and expectations of the target environment, to close the gap between the students' present state of skills and knowledge and the level required by members of the tar-get environment. Instructions aiming at raising students' critical awareness would involve discussion how norms and communicative practices in the target environments become established, encouraging students to critique any negative aspects, and making them aware of ways to try to change or modify the situation so as to position them-selves better in relation to it [28].

To add, H. Widdowson points to two different approaches to the term student needs. The first approach is result-oriented. In this respect student needs are connected with their long-term goals. For example, a longterm goal might be to have work or study opportunities. The second approach to the aforementioned term is process-oriented. It is connected with the whole study process and it is comprised of definite tasks (attending lectures, working on home assignments, participating in seminars, passing tests and examinations, undergoing internship training, collaborating with peers and professors) students have to fulfill in order to become professionals in the field [29].

As tourism graduates work in multicultural organizations and are in contact with international tourists of various nationalities and ethnic groups, they must acquire knowledge and develop skills that will enhance their ability to adapt to different unpredictable situations. The development of mobile technology and the proliferation of smart phones have enabled many of us to access the internet and a huge variety of apps on the go. Learners benefit too, from apps like WIBBU, and podcasts like Luke's English Podcast - Learn British English with Luke Thompson - nominated for an ELTons award in the category of digital innovation.

Teachers are also able to build on their teaching knowledge and skills by listening to podcasts like The TEFL Commute or join 50,000 teachers from more than 200 countries and watch webinars or archived videos of talks by TEFL teachers on EFL Talks. Both are nominated for an ELTons for innovation in teacher resources.

And if teachers and students are gaining so much from their mobile devices, why ban them from classrooms? It seems that getting students to bring their own devices to class is fast becoming a gamechanger in ELT practice [30].

For teacher $\mathrm{C}$. Jones, tools like WhatsApp and Padlet help build channels of communication beyond the classroom. She says that she doesn't often have the hardware or the connectivity in teen classes to use 
internet, so students using their own devices is great - and it means they have a record of the resources we've used to check back on after class [30].

So, the findings of the information technology application are presented in the following implementations.

Information technologies implementation \#1: Communicating with people online. The ability to communicate online with people outside the classroom via Skype and similar tools has enabled students to meet and interact with others in English. In monolingual classes (i.e., most English classrooms around the world), this could give much-needed motivation to students who otherwise might not have the opportunity to interact with anyone in English. And as for teachers, the ability to converse with students face-to-face online has opened up a whole new market for Skype lessons and online classes [30].

Information technologies implementation \#2: Using online authentic materials. One of the biggest benefits of the internet for language learners is the sudden widespread availability of authentic resources. As D. Deubelbeiss points out, that this enables teachers to use content with messages students want to hear. But with so much content available to us, choosing the right online materials is crucial for efficient and effective learning. Keynote by National Geographic Learning, makes use of TED talks to develop a pedagogically sound approach to language learning, while Language Learning with Digital Video looks at how teachers can use online documentaries and YouTube videos to create effective lessons. Both resources are nominated for this year's ELTons awards [30].

Information technologies implementation \#3: the IWB (interactive white board). The IWB started appearing in classrooms in the early parts of this century and has now become a staple of many classrooms in Britain and around the world. It allows us to save and print notes written on the board, control the classroom computer from the whiteboard, play listening activities on the sound system, use the screen as a slide for presentations, access the internet, and so on. The possibilities seem endless. But the addition of an IWB to a classroom does not automatically make for a better learning experience. Indeed, unless teachers use them skilfully to complement teaching and learning, they are little more than a distraction. As teacher

D. Dodgson explains, some people 'love the shiny stuff', believing that simply standing in front of an IWB is effective integration of education technology.

Information technologies implementation \#4: Dogme approach: materials-light teaching. For teachers like M. Noble, discovering the Dogme approach to language teaching was 'galvanizing'. A communicative approach that eschews published textbooks in favor of conversational communication between learners and teacher, Dogme signals a departure from a one-size-fits-all approach to classroom materials.

For many teachers, this "unplugged" approach represents a new way of looking at the lesson content, and the chance to break free from self-contained language points and give more time to student-generated language.

Information technologies implementation \#: Students steering their own learning. Over the last couple of decades, learning has gradually been moving from a teacher-centered top-down approach to a studentcentered, bottom-up one. The trend has accelerated rapidly in recent years with the growing quantity and quality of information on the internet. In many respects, this has changed the teacher's role from that of knowledge-transmitter to consultant, guide, coach, and/or facilitator [30].

One example is the "negotiated syllabus", previously the domain of the business English teacher, who would conduct a needs analysis before tailoring a course to suit the participants. But we've come to recognize that there is nothing general about the general English learner either, and increasingly, teachers involve students in decisions about what to do in the classroom [30].

The ELTons-nominated Connections E-textbook takes this a step further and involves the students in the design of their e-textbook, allowing them to make decisions on page layout and the clarity of task instructions.

Information technologies implementation \#6: Teaching soft skills and critical thinking skills. As English cements its position as the world's lingua franca, many of our students are now learning English to oil the wheels of communication in the worlds of business, trade, education, and tourism. To enable our students to become better communicators, we should perhaps go beyond grammar, vocabulary and pronunciation, and look at helping them communicate effectively in international settings. 
Learner resources nominated for an ELTons award this year include Richmond Business Theories (Richmond ELT), which features online resources that help teachers and students with soft skills like problemsolving, presentation skills, time management and decision-making. Academic Presenting and Presentations (Levrai and Bolster) looks specifically at the communication skills needed when making a presentation at college or university.

Another ELTons nominee is The Thinking Train, which believes in starting young. It helps children develop critical thinking skills that could support them not just in their English learning but in the learning of other subjects and life skills.

And perhaps it is this ability to think and reflect that will enable us as teachers and learners to take any innovation out there and make it work in our context for our students. After all, he is confident that it's never the tool, but the user that makes the difference[30].

To sum up, this part of our study has showed that both the students and the tourism professionals are considered to possess the such most important knowledge, skills and abilities for successful operation in the tourism business as follows: the knowledge of communication psychology, abilities to communicate with clients and colleagues, English language skills, the ability to work in a multicultural team, a positive attitude to work, organizational skills, the ability to apply theoretical knowledge in practice, official language skills, IT skills, initiative, and strategic approach to entrepreneurship and creativity. Indeed, based on work experience the employers, contrary to the students, find the knowledge of marketing, finances, and accounting very significant.

Structural-functional model of practical information technologies application into English for tourism studying process. Empiric research was based on the topic "Global Tourism: International benefits along with Threats".

So, the results are presented in the logic structural-functional model which consists of TEN parts. Each of them is aimed to apply information technologies resources:

1. Open the group discussion by paraphrasing the quotations below. Which one do you agree with? Why?

- 'Travel isn't always pretty. It isn't always comfortable. Sometimes it hurts, it even breaks your heart. But that's okay. The journey changes you; it should change you. It leaves marks on your memory, on your consciousness, on your heart, and on your body. You take something with you. Hopefully, you leave something good behind." - Anthony Bourdain

- "Traveling - it leaves you speechless, then turns you into a storyteller." Ibn Battuta

- "We travel, some of us forever, to seek other places, other lives, other souls." - Anais Nin

- "A journey is best measured in friends, rather than miles." - Tim Cahill

- "Travel makes one modest. You see what a tiny place you occupy in the world." - Gustave Flaubert

- "The man who goes alone can start today; but he who travels with another must wait till that other is ready." - Henry David Thoreau

- "Broad, wholesome, charitable views of men and things cannot be acquired by vegetating in one little corner of the earth all of one's lifetime." - Mark Twain

- "Man cannot discover new oceans unless he has the courage to lose sight of the shore." - Andre Gide

2. Show what you know. Study the following vocabulary giving extensive explanations; come up with statements including some of them as well as try to add couple of your own to this list. Consider the presented tips for using lexis (table1):

-Look carefully through the list to make sure you know the words and are confident that you can use them in your written or spoken English.

-Look up the meaning of any new words and put them in a sentence. If you're not sure your sentence is correct, post it in the comments section at the bottom of the page and we'll check it for you.

-Make a handwritten note of any new words, ideally in a separate note pad that you carry with you. Whenever you have a few minutes - waiting for a bus, just before going to sleep, waiting for the kettle to boil take out the list and look through, reminding yourself of the word and the meaning.

-Improving your vocabulary for IELTS takes practice, so try to use the new word(s) in any suitable situation over the next few weeks - using the new word will help you remember it! 
-Write the new word a number of times - writing down vocabulary will help you remember it and will also help with spelling.

Table 1. Vocabulary "Tourism"

\begin{abstract}
Airport check-in fly land landing plane take off destination journey passenger route travel travel agent trip camp go camping charger flight cruise excursion (youth) hostel hotel luggage motel package holiday selfcatering holiday sightseeing go sightseeing suitcase tour tourism tourist vacation bus station car coach coach station lane motorbike motonway rail go by rail railway railway station road main road minor road boat crossing ferry port sail sea set sail ship voyage ABTA the Association of British Travel Agents agritourism in the countryside attraction enjoyable beauty countryside that attracts tourists Butlins groups of buildings containing restaurants, swimming pools, bars, places to sleep where people can spend their holiday a lot of free entertainment for visitors courier look after tourists on an organized holiday ecotourism the business of creating and selling holidays that give people the chance to learn about a natural environment, and cause as little damage to the environment as possible gondolier to take people for rides in a gondola in Venice guide guidebook a book for tourists that provides information about a place heritage centre a building where tourists and other visitors get information about a place and its people, including information about the natural features of the area high season World Health Organization (WHO) World Industry Council on the Environment (WICE) World Leisure and Recreation Association (WLRA) World Travel and Tourism Council (WTTC) Union of International Fairs (UIF) Pacific Asia Travel Association (PATA) Multinational Meetings Information Services BV Nordic Hotel and Restaurant Association
\end{abstract}

3. Reading comprehension with deep analysis of its parts and content as well.

3.1. Read the article and translate it into Ukrainian.

3.2. Discuss the meanings of the highlighted words and phrases in the article.

3.3. Write the plan to the text and summarize it in a written form using the following linking devices (table 2):

Table 2. Plan to the text

\begin{tabular}{|c|c|c|}
\hline $\begin{array}{l}\text { First(ly) } \\
\text { First of all } \\
\text { For a start } \\
\text { In the first place } \\
\text { Initially } \\
\text { To begin/start } \\
\text { with } \\
\text { Let us begin/start } \\
\text { by } \\
\text { First and foremost } \\
\text { First and most } \\
\text { importantly } \\
\text { Due to / due to } \\
\text { the fact that } \\
\text { Owing to / owing } \\
\text { to the fact that } \\
\text { Because } \\
\text { Because } \\
\text { Since of } \\
\text { As }\end{array}$ & $\begin{array}{l}\text { Second(ly)/third(ly) } \\
\text { In the second place } \\
\text { Subsequently } \\
\text { Simultaneously } \\
\text { And then } \\
\text { Next } \\
\text { Formerly/previously } \\
\text { Both... and ... } \\
\text { Analogously } \\
\text { Equally } \\
\text { Likewise } \\
\text { Just like } \\
\text { Similarly } \\
\text { Correspondingly } \\
\text { In the same way } \\
\text { In the same manner } \\
\text { By the same token } \\
\text { Alternatively } \\
\text { Butl } \\
\text { However }\end{array}$ & $\begin{array}{l}\text { ConverselylOn the contrary } \\
\text { Even thoughlAlthough } \\
\text { In spite ofDespite } \\
\text { Differing fromlIn contrastIInstead } \\
\text { In comparison } \\
\text { In reality } \\
\text { On the one handIOn the other hand } \\
\text { NotwithstandingINonethelessINevertheless } \\
\text { StillYYet } \\
\text { Unlike } \\
\text { WhereasIWhile } \\
\text { Summing up/to sum up } \\
\text { To conclude/in summary } \\
\text { Finally } \\
\text { In short/in brief } \\
\text { On the whole } \\
\text { Ultimately } \\
\text { Last/lastly } \\
\text { Last of all } \\
\text { Last but not the least }\end{array}$ \\
\hline
\end{tabular}


4. Get acquainted with two scientific researches concerning advantages and disadvantages of internet communication skimming together with scanning two texts below. Prove the content comprehension with 10 questions for groupmates' discussion. Exchange the list of enquiries with other partners in form of dialogues and mini-presentations.

5. Translate in a written form into Ukrainian one of the passages taken from any of above texts.

6. Write a opinion essay based on topic "Impact of Globalization on Tourism: Positive and Negative Outcomes" applying the following linkers: to express opinion, in my opinion, personally, I think I believe (that I strongly believe that, it is clear (to me) that, I(completely) agree/disagree with, it seems to me that, as I see it, in my view, from my point of view, as far I am concerned, I am sure/ convinced that, I (dis)agree with the statement, because my main reason is/another reason, one reason for is, many people say/ believe that, because, since, because of/ due to.

7. Broadly applying various possible modern translation techniques and appliances (paper Cambridge dictionary, on-line translation, on-line dictionaries) change the following into Ukrainian putting it in your own words. Comment on what you have read.

8. Переконливих причин, щоб подорожувати частіше

Подорож - це завжди можливість відкрити щось нове та відпочити тілом й душею. Деякі люди народжуються з любов'ю до подорожей і проводять своє життя, шукаючи нові враження. Інші ж планують свої щорічні відпустки, вихідні, які проводять теж поза домівкою. Ваша подорож не обов'язково повинна бути тривалою. Провівши один день поза звичною атмосферою, досліджуючи нове місто, ви відкриєте в собі нові можливості, приховані вміння та наповнитесь незабутніми емоціями.

Відпочинок. Якщо ви перебуваєте далеко від щоденного стресу, ваше тіло і розум відпочиває. Окрім цього, ви отримуєте новий досвід та вчитесь тримати свої думки подалі від щоденних проблем. Завдяки цьому ви можете зосередитись на тому, що бачите - пам'ятки, запахи, звуки та інше. Через кілька днів ви відчуєте, що ваше тіло починає розслаблятись.

8. Complete the essential vocabulary table "Parts of Speech" incorporating active glossary extracted from translated article (table 3).

Table 3. Parts of Speech

\begin{tabular}{|l|l|l|l|l|}
\hline Nouns & Verbs & Adjectives & Adverbs & $\begin{array}{l}\text { Other (Set Expressions, } \\
\text { Phrasal Verbs, Idioms, } \\
\text { Collocations) }\end{array}$ \\
\hline Tourism & Visit & Amazing & Quickly & Cover a lot of ground \\
\hline
\end{tabular}

9.1. Speech etiquette in modern communication! Be creative in finding the most appropriate English equivalents to the frequently used idioms, phrases in today's business environment.

1. в адміністративному порядку. 2. спека, як у пеклі, нестерпна (нестерпуча, страшенна) нудота (нудьга)). 3. як з воску вилити. 4. відкрив Америку! 5. Не їсться, не п'ється, і серце не б'ється, апетит приходить під час їжі. 6. Перший шматок з'їси усмак, а другий уже не так. 7. митець (мастак) у своєму ділі (у своїй справі). 8. продати з аукціону (з торгів, з молотка); цінувати, поцінувати. 9. наказати (наверзти, намолоти) сім мішків (три мішки) гречаної вовни; наказати на вербі груш; смаленого дуба плести. 10. зчинити ґвалт (галас, лемент, гармидер, рейвах), приводити, привести кого до банкрутства; завдавати, завдати кому банкрутства; вивернути кому кожуха.

9.2. Research activity: complete this list looking for as more as possible the newest expressions lately appeared in modern speaking on business.

10. Make a project on theme "Popular Types of Tourism in Ukraine as well as around the Globe" in three possible deliveries: a) presentation in front of audience with personal speech and comments; b) written reportanalysis based on collective data from various sources; c) multimedia option presented by means of selected topical video [31].

Accordingly, giving general characteristics to the structural-functional model, it should be noted that all ten elements are aimed to implement different internet resources in order to make English for Tourism learning process as effective and resultfull as it is possible. 


\section{Discussion}

Above all, the world faces many challenges, of which one of the most important is creating the tourism professionals of tomorrow. In this situation a special role is given to universities as the leading force in educating the younger generation who will be entering the labour market in the near future and will be responsible for developing industry and society. As they will be working in conditions no one can currently predict, it is especially important to promote the foreign language professional competence of future tourism area specialists as well as the generic competences that would enable them to learn fast, adapt to new circumstances and creatively develop their industry.

Thus, the role of universities is increasing all over the word. However, to strive for a common aim, university professors have to work hand-in-hand with the industry representatives thus contributing to the creation of new curricula and updating the existing ones in accordance with the needs of the industry and considering the requirements of the whole society. This can be done by conducting joint studies, and by exploring the needs and wishes of stakeholders in order to create updated curricula that could be successfully implemented in the next decade as well.

\section{Conclusion}

In conclusion, we may say that information technology is indivisible part of education in the twenty-first century. When used correctly in the classroom, technology can allows tourism area students to experience situations and circumstances that the students of 20 years ago could only dream about.

Again, through technology, books and figures can suddenly become alive and applicable to the real world. In addition, information technology provides an even greater avenue for interaction between teacher and students. At the English lessons different videos, exercises, games, listening drills may be done. Information technology makes learning English available to a wider range of learners as well.

Especially, the concept of English for Tourism is multispectral and multi-strained. Its appearance has proved to be an apparent result and urgent necessity on the changes the science and society in general faced with due to drastic and global processes taken their place starting from the second half of the 20th century.

Future investigations prospects. To our mind, future investigations might be streamlined to deeply discover the answers to the following research questions:

- "What knowledge, skills, abilities and attitude are important to work in the tourism business?"

- " How do employers and students evaluate student knowledge in tourism courses and how are skills and abilities developed?"

- "How can tourism curriculum be improved in order to enable students to acquire an up-to-date tourism education?".

\section{References}

1. Acar, K. (2004). Globalization and language: English in Turkey. Journal of Social Sciences, Vol. 2, no. 1, 1-10.

2. Appadurai, A. (2001). Globalization. Durham. Durham. USA: Duke University Press.

3. Hismanoglu, M. (2012). The impact of globalization and information technology on language education policy in Turkey. Procedia - Social and Behavioral Sciences, No 31, 629-633. URL: https://pdf.sciencedirectassets.com/277811/1-s2.0S1877042811X00241/1 (accessed 10.02.2020).

4. Alev, N. (2003). Integrating Information and Communications Technology (ICT) into Pre-service Science Teacher Education: The Challenges of Change in a Turkish Faculty of Education. School of Education. UK: University of Leicester.

5. Altun, T. (2007). Information and Communications Technology (ICT) in Initial Teacher Education: What can Turkey learn from Range of International Perspectives? Journal of Turkish Science Education, Vol. 4, № 2, 45-60,.

6. Block , D., Cameron, D. (2002). Introduction. Globalization and Language Teaching. London: Routledge.

7. Rodinadze S., Zarbazoia K. (2012). The Advantages of Information Technology in Teaching English Language. Frontiers of Language and Teaching, Vol. 3., $271-275$.

8. Akkoyunlu, B. (2002). Educational technology in Turkey. Educational Media International, Vol. 39, №2., 165-174,.

9. Akşit, N. ( 2007). Educational reform in Turkey. International Journal of Educational Development, Vol.27, №2., 129-137.

10. Mamadaiupova, Sh. (2017). The role of information technologies in improving the quality of vocational education, Young scientist, №24, 418-420.

11. Grynyuk S. (2016). Foreign Language Teaching for Specific Purposes: Basic Aspects, Scientific Journal «ScienceRise, № 3, 18-23.

12. Hutchinson, T. (1987). English for Specific Purposes: A learner-centered approach. Cambridge: Cambridge University Press. 
13. Mohammad, K. (2014.). The ESP Teacher: Issues, Tasks and Challenges. English for Specific Purposes World, Vol. 15, № 42, 1 - 33. URL: http://www.esp-world.info/Articles_42/Documents/Ahmed.pdf (accessed 02.02.2020).

14. Dudley-Evans,T. (1998). Developments in English for Specific Purposes: A multi-disciplinary approach. Cambridge: Cambridge University Press.

15. Strevens, P. (1988). ESP after twenty years: a re-appraisal. ESP: State of the art. SEAMEO: Regional Language Centre.

16. Basturkmen, H. (2010). Developing Courses in English for Specific Purposes. Palgrave: Macmillan, London.

17. [Basturkmen, H. (2005). Ideas and Options in English for Specific Purposes. London: Lawrence Erlbaum Associates, Inc., Publishers.

18. Stern, H. (1992). Issues and options in language teaching. Oxford: Oxford University Press.

19. Johns A. English for Specific Purposes: International in Scope, Specific in Purpose. TESOL Quarterly. 1991, Vol. 25, №. 2,. 200-297.

20. Ellis, R. (2003). Task-Based Language Learning and Teaching. Oxford: Oxford University Press.

21. McGrath, I. (2002). Materials Evaluation and Design for language Teaching. Edinburgh: Edinburgh University Press.

22. Douglas, D. (2013). Needs Analysis and Curriculum Development. Oxford: Wiley Blackwell.

23. Benesch, S. (2001). Critical English for Academic Purposes: Theory, politics and practice. Mahwah, NJ: Lawrence Erlbaum Associates.

24. The Uses of Information Technology in Education (2015). URL: https://fedena.com/blog/2015/11/the-uses-of-informationtechnology-in-education.html (accessed 04.02.2020).

25. Role of Information Technology in Education (2018). URL: https://khaitanpublicschool.com/blog/information-technology-ineducation/ (accessed 28.01.2020).

26. Shaikina, O. (2016). Information Technology in English Language Teaching. Podcasting in Higher Education, Young scientist, №6, 287-289.

27. [27] Sangpikul, A. (2009). Internationalization of Hospitality and Tourism Higher Education: A Perspective from Thailand, Journal of Teaching in Travel and Tourism, Vol.9, №.1, 2-20.

28. Robinson, P. (1991). ESP Today: a Practitioner's Guide. Hemel Hempstead: Prentice Hall International.

29. Widdowson, H. (1986). Explorations in Applied Linguistics. Oxford: Oxford University Press.

30. Ten innovations that have changed English language teaching By Chia Suan Chong (2016). URL: https://www.britishcouncil.org/voices-magazine/ten-innovations-have-changed-english-language-teaching. (accessed 25.01.2020).

31. Vasylyshyna, N.M., Skyrda, T.S. (2020). Pereklad yak mizhkulturna komunikatsiia: anhliiska $\leftrightarrow$ ukrainska movy: praktykum dlia studentiv dennoi formy navchannia haluzi znan 0302 «Mizhnarodni vidnosyny». [Translation as Intercultural Communication: English $\leftrightarrow$ Ukrainian: Workshop for Full-time Students in the Knowledge Field 0302 International Relations]. Kyiv.

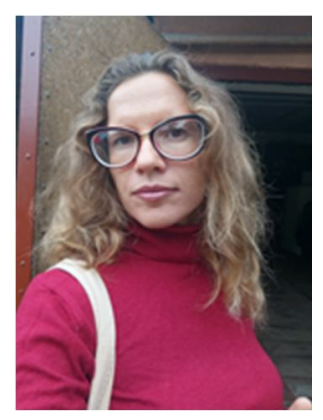

\section{Василишина Наталія Максимівна,}

Канд.пед.наук, доцент, доцент кафедри іноземних мов,

Національний авіаційний університет,

м.Київ, проспект Відрадний, 4.

Тел. (068)59-30-727. E-mail: filologyN@gmail.com

Vasylyshyna Nataliia Maksymivna,

Ph.D. in Pedagogics, Associate Professor, Associate Professor of Foreign Language Department

National aviation university, Kyiv, Ukraine,

Address. Otradnyy Av., 4

Тел. (068)59-30-727. E-mail: filologyN@gmail.com

ORCID: 0000-0002-0003-9998

Researcher ID: H-1189-2019

\section{Citation (APA):}

Vasylyshyna, N. (2020). Empiric research related to information technologies application in professional English learning process for tourism specialty students. Engineering and Educational Technologies, 8 (1), 59-73. doi: https://doi.org/10.30929/2307-

9770.2020 .08 .01 .05

\section{Цитування (ДСТУ 8302:2015):}

Василишина Н. М. Емпіричне дослідження стосовно застосування інформаційних технологій у процесі вивчення професійної англійської мови студентами спеціальності «туризм» / Інженерні та освітні технології. 2020. Т. 8. № 1. С. 59-73. doi: https://doi.org/10.30929/2307-9770.2020.08.01.05

Обсяг статmі: $\quad$ сторінок - 15 ; умовних друк. аркушів - 2,173. 